\title{
Using systematic data categorisation to quantify the types of data collected in clinical trials: the DataCat project
}

Evelyn Crowley ${ }^{1}$, Shaun Treweek ${ }^{2^{*}}$ (D) Katie Banister ${ }^{2}$, Suzanne Breeman ${ }^{3}$, Lynda Constable ${ }^{3}$, Seonaidh Cotton ${ }^{3}$, Anne Duncan ${ }^{3}$, Adel El Feky ${ }^{2}$, Heidi Gardner ${ }^{2}$, Kirsteen Goodman ${ }^{4}$, Doris Lanz ${ }^{5}$, Alison McDonald ${ }^{3}$, Emma Ogburn ${ }^{6}$, Kath Starr ${ }^{3}$, Natasha Stevens ${ }^{7}$, Marie Valente ${ }^{8}$ and Gordon Fernie ${ }^{3}$

\begin{abstract}
Background: Data collection consumes a large proportion of clinical trial resources. Each data item requires time and effort for collection, processing and quality control procedures. In general, more data equals a heavier burden for trial staff and participants. It is also likely to increase costs. Knowing the types of data being collected, and in what proportion, will be helpful to ensure that limited trial resources and participant goodwill are used wisely.

Aim: The aim of this study is to categorise the types of data collected across a broad range of trials and assess what proportion of collected data each category represents.

Methods: We developed a standard operating procedure to categorise data into primary outcome, secondary outcome and 15 other categories. We categorised all variables collected on trial data collection forms from 18, mainly publicly funded, randomised superiority trials, including trials of an investigational medicinal product and complex interventions. Categorisation was done independently in pairs: one person having in-depth knowledge of the trial, the other independent of the trial. Disagreement was resolved through reference to the trial protocol and discussion, with the project team being consulted if necessary.
\end{abstract}

Key results: Primary outcome data accounted for 5.0\% (median)/11.2\% (mean) of all data items collected. Secondary outcomes accounted for $39.9 \%$ (median)/42.5\% (mean) of all data items. Non-outcome data such as participant identifiers and demographic data represented 32.4\% (median)/36.5\% (mean) of all data items collected.

Conclusion: A small proportion of the data collected in our sample of 18 trials was related to the primary outcome. Secondary outcomes accounted for eight times the volume of data as the primary outcome. A substantial amount of data collection is not related to trial outcomes. Trialists should work to make sure that the data they collect are only those essential to support the health and treatment decisions of those whom the trial is designed to inform.

\section{Introduction}

Data collection consumes a large proportion of trial resources. Each data item requires time and effort for collection, processing and quality control procedures [1]. Generally speaking, more data equals a heavier burden

\footnotetext{
* Correspondence: streweek@mac.com

${ }^{2}$ Health Services Research Unit, University of Aberdeen, Aberdeen, UK

Full list of author information is available at the end of the article
}

for trial staff and participants. More data may also increase the cost of the trial.

Outcomes are also not created equal. Trials usually have one outcome that is considered primary-the outcome of highest importance in the trial. Ideally, this outcome should be of most interest to stakeholders such as patients, clinicians, policymakers and funders. The primary outcome is normally the outcome used in the 
sample size calculation [2]. However, it is rare for a single outcome to provide enough information about the trial intervention(s) on its own, so it is usual to have secondary outcomes to provide a wider context for the main research question. These outcomes will be detailed in the trial protocol but tend not to drive sample size because they are rarely included in sample size calculations.

An under-recognised challenge in conducting a clinical trial is ensuring that the data collected are sufficient to answer the trial research questions but are not so substantial as to threaten the feasibility of the trial. As the primary outcome is the measurement that will be used to evaluate the effectiveness of the intervention, it seems reasonable to expect that it will receive a substantial part of the data collection effort (and funding). It is not clear that this is currently the case.

Data collection covers more than outcomes. Trials collect demographic, medical history, safety and regulatory non-outcome data, as well as generating their own data in the form of identifiers and process checks (e.g. 'was leaflet $\mathrm{X}$ handed out? Y/N'). For drug trials in particular, evaluations may be focused on differentiating similar, competing therapies by incremental differences in one or all of safety, efficacy [3] and health economic measures, which can require a substantial amount of data. Growing requirements and requests from regulators and sponsor organisations have also increased the amount of data that routinely needs to be collected in clinical trials [3-5]. The amount of secondary, exploratory and auxiliary data in trials can be substantial, with more than half of the outcome data collected for Phase II and Phase III trials being less essential or supplementary [3]. One study of six drug/nutritional supplement trials found 137,008 items of data for 126 participants, of which the authors considered only 18,124 to be key for targeted risk-based monitoring purposes, or just $13 \%$ of all data collected [6].

Trials are collecting more data than ever. Getz and colleagues [7] examined 9737 trial protocols of Phase II and Phase III trials and found that between two time periods (2000-2005 and 2011-2015) the number of planned study visits had increased by $23 \%$ (Phase II) and $25 \%$ (Phase III). Similarly, the total number of trial procedures had also increased by $67 \%$ and $70 \%$, respectively. Both increased data collection requirements. Apart from extra workload, these increases can also adversely affect recruitment and retention rates [7-9]. 'How can trials be designed to minimise burden on staff and participants and how does this affect retention?' was ranked third in a recent prioritisation exercise of unanswered research questions on trial retention [10]. Collecting large amounts of data may also increase missing data. This will reduce the power of the study if it affects the primary outcome and will reduce the power of already potentially underpowered secondary outcome analyses, especially if the data arenot missing at random [11]. Added to this is the possibility that after doing a lot of work, the data are not used anyway. O'Leary et al. [12] found that large proportions of collected data (median $82 \%$, range $73-89 \%$ ) were not reported in associated publications.

We wanted to examine the type and volume of data being collected across a variety of clinical trial types. This paper describes work done in the DataCat project in which we (1) developed a list of categories of data collected in trials and (2) applied that categorisation system to the data collected in trials run in the UK and Ireland. The work was unfunded and done as part of the Trial Forge initiative (www.trialforge.org) to improve trial efficiency.

\section{Methods}

The original idea for this project came from a workshop held at the annual meeting of the UK Trial Managers' Network (UKTMN) in London, UK, on 10th September 2015. ST facilitated the workshop, and around 20 trial managers suggested, then ranked, ideas for research projects addressing important questions relevant to them. The question 'Why do we collect the data we do: what is the purpose of the data we collect on the CRF (case report form) and do we actually use it?' was ranked second and formed the basis of the work done here. (The top ranked question, about electronic versus paper data collection, was considered more difficult to study without funding.) The work described here addresses the first half of the question, i.e. 'What is the purpose of the data we collect on the CRF?'

Shortly after the meeting, we formed a group, mainly composed of trial managers but also trial methodologists, interested in addressing this question; many had attended the London workshop. Over time we expanded the group slightly to include people not present at the workshop, including the addition of a trial data manager.

The work had three stages:

- We developed a standard operating procedure for categorising data.

- We piloted the categories.

- We applied the tested categorisation list to a larger sample of trials.

\section{Stage I: development of a standard operating procedure for data categorisation}

We developed the list of categories iteratively through a series of teleconference discussions where potential categories of data were considered. We drew the data categories from general features of trial protocols (e.g. 
demographics, primary outcomes, secondary outcomes), our experience of running trials (e.g. data required to identify participants or link data) and our experience of initial attempts to apply the list to trial data collection forms (case report forms [CRFs] and participant questionnaires) from three trials (AMBER [13], KAT [14] and SALVO [15]). We identified these trials primarily from personal involvement with the trial; none was a Clinical Trial of an Investigational Medicinal Product (CTIMP). We were interested in definitive trials, often called Phase III trials. Based on this, a standard operating procedure (SOP) was developed for how to categorise the data (see Additional file 1).

\section{Stage II: piloting of the categories}

We piloted the categorisation list and SOP with six trials, including the three with which we developed the process. The three additional trials were also selected based on personal involvement in the trial; we quickly found in Stage I that categorisation needed someone close to the trial. We first listed all the data items collected on the trial data collection forms. We defined data items as the individual pieces of data collected on the trial data collection forms (also called fields or variables). We then assigned each data item on the list to a single data category that best described what type of data it was (i.e. the main reason it was collected). We used the trial protocol to help with this process. Where data items were dependent on events occurring (e.g. repeat visits, an adverse event, drug prescription), the number of data items categorised did not necessarily represent the maximum possible number. Two team members independently categorised the data for each trial, one who was familiar with the trial and one who was not. The two reviewers then met or had a telephone call to discuss and resolve any discrepancies in their categorisations. Some data items were hard to categorise, and discrepancies often involved one of the two reviewers using 'Miscellaneous' where the other did not. For example, in SALVO [15] 'Mother ABO blood group' was initially categorised as 'Miscellaneous' by one person and 'Medical history' by the other. After discussion the two team members agreed that in this case this data item was best described as 'Miscellaneous'. If necessary, the rest of the project team was consulted to resolve a discrepancy.

Having piloted the categorisation list, a new member of the project team (EC) reviewed the same six trials and all sources of discrepancy together with one member of the project team (ST). We refined the categories list and guidance where necessary with agreement from the whole group.

\section{Stage III: application of the tested categorisation list to a} larger sample of trials

We then categorised data items collected in an additional sample of 12 trials (also a convenience sample) using the categorisation list and SOP. As with the pilot, we identified the trials primarily through the personal knowledge of the trial by a project team member. In this final stage we included CTIMPs along with additional non-CTIMPs.

\section{Results}

Stages I and II (creating the categorisation list, standard operating procedure and piloting)

The final list of categories included 17 types of data (Table 1) together with guidance on the type of data each category might contain. This included a hierarchical categorisation process which was developed to handle situations where a data item could potentially be placed into more than one category (see Additional file 1 for the guidance document we used when making category decisions).

The review of the six pilot trials led by EC resulted in one new category ('Primary outcome but not primary analysis') and some additional guidance to reduce ambiguity around category choice. The extra category was added to account for cases where the primary outcome (e.g. weight) was measured but at a timepoint (e.g. 12 weeks) that was not the primary outcome measurement point (e.g. 12 months). The SOP was also updated (see Additional file 1).

\subsection{Stage III}

A total of 18 trials were categorised, including the six used in the pilot; 15 complex intervention non-CTIMPs and three CTIMPs, predominantly publicly funded and sponsored by UK academic and/or National Health Service (NHS) institutions. All trials were superiority trials. The 18 trials had different chief investigators, and the teams were either completely, or largely, different. There was some overlap of individuals (e.g. ST was involved in ActWELL and ECLS; EAGLE and TAGS involved some of the same clinicians), but the majority of the trial team were different across all 18 trials. The oldest began in 1998 with the most recent beginning in 2017. The characteristics of the included trials are presented in Table 2. Duration of follow-up ranged from a few days (until discharge) to $10-15$ years, and target sample sizes ranged from 40 to 12,000 trial participants. Trial data collection documents were received from five different institutions in the UK and Ireland.

Proportions of data items within each trial were calculated and those proportions summarised across all 18 trials. Table 3 presents these categorisation results. Primary outcome data accounted for $5.0 \%$ (median)/11.2\% 
Table 1 The 17 data collection categories

\begin{tabular}{|c|c|}
\hline Category & Example \\
\hline \multicolumn{2}{|l|}{ Outcomes } \\
\hline 1. Primary Outcome & As identified in the trial protocol \\
\hline 2. Primary outcome but not primary analysis & $\begin{array}{l}\text { Primary outcome is weight loss at } 12 \text { months but weight loss is also measured at } 3 \\
\text { months }\end{array}$ \\
\hline 3. Secondary Outcomes & As designated in the trial protocol \\
\hline \multicolumn{2}{|c|}{$\begin{array}{l}\text { 4. Outcome data not listed as primary, secondary or health } \\
\text { economics outcome }\end{array}$} \\
\hline \multicolumn{2}{|l|}{ 5. Items from a core outcome set } \\
\hline \multicolumn{2}{|l|}{ 6. Health Economics } \\
\hline \multicolumn{2}{|l|}{ Non-outcomes } \\
\hline 7. Participant identification items & Participant ID, postal contact details, general practitioner name and contact details \\
\hline 8. Items needed for randomisation & Age, sex, site \\
\hline \multicolumn{2}{|l|}{ 9. Eligibility } \\
\hline 10. Demographics & Age, sex, family history of condition of interest \\
\hline \multicolumn{2}{|l|}{ 11. Medical History } \\
\hline 12. Data Management Item & Visit number \\
\hline 13. Safety Data & Concomittant medications \\
\hline 14. Regulatory Data & Deviation logging, reason for withdrawal \\
\hline 15. Compliance Data & $\begin{array}{l}\text { Dose administered, tablets taken or returned, confirmation of completed processes, } \\
\text { randomisation allocation }\end{array}$ \\
\hline 16. Process Outcomes & How much blood was collected, who delivered the educational information \\
\hline 17. Miscellaneous & \\
\hline
\end{tabular}

(mean) of all data items collected. Secondary outcomes constituted the largest proportion of data items collected per participant per trial summarised across all included trials (median 39.9\%; mean 42.5\%). Two trials are notable exceptions to this trend (see Table 2): in ViDiFlu (a National Institute for Health Research [NIHR] programme grant-funded trial of vitamin D for prevention of influenza and other respiratory infections), primary outcomes accounted for the largest proportion of data items collected (50.3\%), while in HIP (an EUfunded trial of hypotension management in extremely low gestational age newborns), safety data (21.1\%) and compliance data (21.1\%) accounted for the largest proportions of data items collected. Indeed, in ViDiFlu so many data items were for primary outcomes (5096 or $78.1 \%$ of the overall total from all 18 trials) that their inclusion inflates the average proportion of primary outcomes. These exceptions may relate to the nature of the trials-for example, HIP involves newborns, which may explain why it collected a lot of safety and compliance data-or to the trials' funding streams, which were different to the majority of trials in our sample, which were largely funded by NIHR-Health Technology Assessment (HTA) or the Chief Scientist Office of the Scottish Government.
Table 4 summarises the categorisation results across CTIMPs and non-CTIMPs separately. For CTIMPs, secondary outcomes (median 33.8\%; mean 24.8\%), safety data $(16.9 \% ; 16.4 \%)$, regulatory data $(11.5 \% ; 11.7 \%)$ and participant identification items $(9.9 \% ; 8.9 \%)$ constituted the largest proportion of data items collected.

For non-CTIMPs, secondary outcomes (median 45.2\%; mean $46.0 \%)$, primary outcomes $(5.5 \% ; 10.8 \%)$, data management outcomes (4.7\%; 5.3\%) and participant identification items $(4.5 \%$; $4.0 \%)$ constituted the largest amount of data items collected.

Non-outcome data accounted for the vast majority (median 61.7\%; mean 61.1\%) of data items collected in CTIMPs as compared with about a third $(27.4 \% ; 31.6 \%)$ of data items collected in non-CTIMPs.

\section{Discussion}

\section{General results}

For our 18 trials a small proportion of all the data items collected, a median of $5.0 \%$, were for the primary outcome assessment-the outcome assessment considered by the trialists themselves to be of the highest importance in their trial. The median of $5.0 \%$ is the better measure due to one trial, ViDiFlu, devoting half of its data items to the primary outcome. 
Table 2 Characteristics of included categorised trials

\begin{tabular}{|c|c|c|c|c|c|c|}
\hline Acronym & Full title & Funder & $\begin{array}{l}\text { Funding start - } \\
\text { end } \\
\text { (month/year) }\end{array}$ & $\begin{array}{l}\text { Follow- } \\
\text { up } \\
\text { duration }\end{array}$ & Sample size & $\begin{array}{l}\text { Trial received } \\
\text { from }\end{array}$ \\
\hline ActWELL & $\begin{array}{l}\text { A randomised controlled trial to assess the } \\
\text { impact of a lifestyle intervention (ActWELL) in } \\
\text { women invited to NHS breast screening }\end{array}$ & $\begin{array}{l}\text { The Scottish } \\
\text { Government }\end{array}$ & $\begin{array}{l}\text { Jan } 2017-\text { Dec } \\
2019\end{array}$ & $\begin{array}{l}12 \\
\text { months }\end{array}$ & 414 & $\begin{array}{l}\text { University of } \\
\text { Dundee }\end{array}$ \\
\hline AMBER & $\begin{array}{l}\text { Abdominal massage for neurogenic bowel } \\
\text { dysfunction in people with multiple sclerosis }\end{array}$ & $\begin{array}{l}\text { National Institute for } \\
\text { Health Research - } \\
\text { Health Technology } \\
\text { Assessment } \\
\text { (NIHR-HTA) } \\
\text { programme }\end{array}$ & $\begin{array}{l}\text { July } 2014 \text { - June } \\
2017\end{array}$ & 6 months & 200 & $\begin{array}{l}\text { NMAHP } \\
\text { Research Unit, } \\
\text { Glasgow } \\
\text { Caledonian } \\
\text { University }\end{array}$ \\
\hline CONFIDeNT & $\begin{array}{l}\text { CONtrol of Faecal Incontinence using Distal } \\
\text { NeuromodulaTion }\end{array}$ & $\mathrm{NIHR}-\mathrm{HTA}$ & $\begin{array}{l}\text { Feb } 2012-\text { Apr } \\
2014\end{array}$ & 14 weeks & 212 & $\begin{array}{l}\text { Queen Mary } \\
\text { University } \\
\text { London }\end{array}$ \\
\hline EAGLE & $\begin{array}{l}\text { Whether removal of the lens of the eye (lens } \\
\text { extraction) for newly diagnosed primary angle } \\
\text { closure glaucoma results in better patient- } \\
\text { reported health vision, lower intraocular pres- } \\
\text { sure and other outcomes compared with stand- } \\
\text { ard management }\end{array}$ & $\begin{array}{l}\text { NIHR - Efficacy and } \\
\text { Mechanism } \\
\text { Evaluation } \\
\text { (NIHR-EME) }\end{array}$ & $\begin{array}{l}\text { Nov } 2008 \text { - July } \\
2015\end{array}$ & 3 years & 419 & $\begin{array}{l}\text { CHaRT, } \\
\text { University of } \\
\text { Aberdeen }\end{array}$ \\
\hline ECLS & $\begin{array}{l}\text { Detection in blood of autoantibodies to tumour } \\
\text { antigens as a case-finding method in lung can- } \\
\text { cer using the EarlyCDT-Lung test }\end{array}$ & $\begin{array}{l}\text { Chief Scientist Office, } \\
\text { Scottish } \\
\text { Government and } \\
\text { Oncimmune Ltd }\end{array}$ & $\begin{array}{l}\text { Aug } 2013-\text { Aug } \\
2018\end{array}$ & $\begin{array}{l}24 \\
\text { months }\end{array}$ & 12,000 & $\begin{array}{l}\text { University of } \\
\text { Dundee }\end{array}$ \\
\hline EMPiRE & $\begin{array}{l}\text { AntiEpileptic drug Monitoring in PREgnancy: an } \\
\text { evaluation of effectiveness, cost-effectiveness } \\
\text { and acceptability of monitoring strategies }\end{array}$ & NIHR-HTA & $\begin{array}{l}\text { Sept } 2011-\text { Apr } \\
2016\end{array}$ & $\begin{array}{l}21 \text { weeks } \\
\text { approx. }\end{array}$ & 1000 & $\begin{array}{l}\text { Queen Mary } \\
\text { University } \\
\text { London }\end{array}$ \\
\hline Acronym & Full title & Funder & $\begin{array}{l}\text { Funding start - } \\
\text { end } \\
\text { (month/year) }\end{array}$ & $\begin{array}{l}\text { Follow- } \\
\text { up } \\
\text { duration }\end{array}$ & Sample size & $\begin{array}{l}\text { Trial received } \\
\text { from }\end{array}$ \\
\hline HEALTH & $\begin{array}{l}\text { A multicentre randomised controlled trial } \\
\text { comparing laparoscopic supra-cervical hysterec- } \\
\text { tomy with second generation endometrial abla- } \\
\text { tion for the treatment of heavy menstrual } \\
\text { bleeding }\end{array}$ & NIHR-HTA & $\begin{array}{l}\text { Jan } 2014-\text { Sep } \\
2018\end{array}$ & $\begin{array}{l}15 \\
\text { months }\end{array}$ & 648 & $\begin{array}{l}\text { CHaRT, } \\
\text { University of } \\
\text { Aberdeen }\end{array}$ \\
\hline HIP & $\begin{array}{l}\text { Management of Hypotension In the Preterm: a } \\
\text { multicentre, randomised controlled trial of } \\
\text { hypotension management in the extremely low } \\
\text { gestational age newborn }\end{array}$ & $\begin{array}{l}\text { European } \\
\text { Commission within } \\
\text { the } 7 \text { th Framework } \\
\text { Programme }\end{array}$ & $\begin{array}{l}\text { Oct } 2010-\text { Sep } \\
2017\end{array}$ & 2 years & 340 & $\begin{array}{l}\text { INFANT Centre, } \\
\text { Cork, Ireland }\end{array}$ \\
\hline iQuaD & $\begin{array}{l}\text { A multicentre randomised controlled trial } \\
\text { comparing oral hygiene advice and periodontal } \\
\text { instrumentation for the prevention and } \\
\text { management of periodontal disease in dentate } \\
\text { adults attending dental primary care }\end{array}$ & NIHR-HTA & $\begin{array}{l}\text { Apr } 2011-\text { Dec } \\
2016\end{array}$ & $\begin{array}{l}36 \\
\text { months }\end{array}$ & 1860 & $\begin{array}{l}\text { University of } \\
\text { Dundee \& } \\
\text { CHaRT, } \\
\text { University of } \\
\text { Aberdeen }\end{array}$ \\
\hline KANECT ${ }^{a}$ & $\begin{array}{l}\text { The use of ketamine as an anaesthetic during } \\
\text { electroconvulsive therapy (ECT) for depression: } \\
\text { does it improve treatment outcome? }\end{array}$ & $\begin{array}{l}\text { Chief Scientist Office - } \\
\text { Scottish Government } \\
\text { Health Directorate }\end{array}$ & $\begin{array}{l}\text { Apr } 2011-\text { Apr } \\
2014\end{array}$ & 1 month & 40 & $\begin{array}{l}\text { CHaRT, } \\
\text { University of } \\
\text { Aberdeen }\end{array}$ \\
\hline KAT & Knee Arthroplasty Trial & $\mathrm{NIHR}-\mathrm{HTA}$ & $\begin{array}{l}\text { Dec } 1998- \\
\text { June } 2023\end{array}$ & $\begin{array}{l}10-15 \\
\text { years }\end{array}$ & 2450 & $\begin{array}{l}\text { CHaRT, } \\
\text { University of } \\
\text { Aberdeen }\end{array}$ \\
\hline PIMS & $\begin{array}{l}\text { A randomised controlled trial comparing face- } \\
\text { down and face-forward positioning after eye } \\
\text { surgery for macular holes to see if this improves } \\
\text { the rate of macular hole closure }\end{array}$ & $\mathrm{NIHR}-\mathrm{HTA}$ & $\begin{array}{l}\text { Apr } 2015-\text { Apr } \\
2018\end{array}$ & 3 months & 192 & $\begin{array}{l}\text { Queen Mary } \\
\text { University } \\
\text { London }\end{array}$ \\
\hline SALVO & $\begin{array}{l}\text { A Randomised Controlled Trial of Intra- } \\
\text { Operative Cell Salvage during Caesarean Sec- } \\
\text { tion in Women at Risk of Haemorrhage }\end{array}$ & $\mathrm{NIHR}-\mathrm{HTA}$ & $\begin{array}{l}\text { Oct } 2012-\text { Oct } \\
2016\end{array}$ & $\begin{array}{l}\text { Until } \\
\text { discharge }\end{array}$ & 3050 & $\begin{array}{l}\text { Queen Mary } \\
\text { University } \\
\text { London }\end{array}$ \\
\hline Acronym & Full Title & Funder & $\begin{array}{l}\text { Funding start - } \\
\text { end } \\
\text { (Month/Year) }\end{array}$ & $\begin{array}{l}\text { Follow- } \\
\text { up } \\
\text { Duration }\end{array}$ & Sample Size & $\begin{array}{l}\text { Trial Received } \\
\text { From }\end{array}$ \\
\hline
\end{tabular}


Table 2 Characteristics of included categorised trials (Continued)

\begin{tabular}{|c|c|c|c|c|c|c|}
\hline Acronym & Full title & Funder & $\begin{array}{l}\text { Funding start - } \\
\text { end } \\
\text { (month/year) }\end{array}$ & $\begin{array}{l}\text { Follow- } \\
\text { up } \\
\text { duration }\end{array}$ & Sample size & $\begin{array}{l}\text { Trial received } \\
\text { from }\end{array}$ \\
\hline SUSPEND ${ }^{a}$ & $\begin{array}{l}\text { Use of drug therapy in the management of } \\
\text { symptomatic ureteric stones in hospitalised } \\
\text { adults: a multicentre placebo controlled } \\
\text { randomised trial of a calcium channel blocker } \\
\text { (nifedipine) and an a-blocker (tamsulosin) }\end{array}$ & NIHR-HTA & $\begin{array}{l}\text { Jun } 2010-\text { Oct } \\
2014\end{array}$ & 12 weeks & 1200 & $\begin{array}{l}\text { CHaRT, } \\
\text { University of } \\
\text { Aberdeen }\end{array}$ \\
\hline TAGS & $\begin{array}{l}\text { Treatment of Advanced Glaucoma Study } \\
\text { (TAGS): a multicentre randomised controlled } \\
\text { trial comparing primary medical treatment with } \\
\text { primary trabeculectomy for people with newly } \\
\text { diagnosed advanced glaucoma }\end{array}$ & NIHR-HTA & $\begin{array}{l}\text { Jan } 2014-\text { Jan } \\
2020^{\mathrm{a}}(\mathrm{LTFU}- \\
\text { Dec } 2023 \text { not } \\
\text { included) }\end{array}$ & 2 years & 440 & $\begin{array}{l}\text { CHaRT, } \\
\text { University of } \\
\text { Aberdeen }\end{array}$ \\
\hline$T_{W}{ }^{2} S^{a}$ & $\begin{array}{l}\text { A randomised, double-blind placebo controlled } \\
\text { trial of the effectiveness of low dose oral theo- } \\
\text { phylline as an adjunct to inhaled corticosteroids } \\
\text { in preventing exacerbations of chronic obstruct- } \\
\text { ive pulmonary disease }\end{array}$ & NIHR-HTA & $\begin{array}{l}\text { July } 2013-\text { Dec } \\
2017\end{array}$ & $\begin{array}{l}12 \\
\text { months }\end{array}$ & 1424 & $\begin{array}{l}\text { CHaRT, } \\
\text { University of } \\
\text { Aberdeen }\end{array}$ \\
\hline ViDiFlu & $\begin{array}{l}\text { Cluster-randomised, double-blind, placebo- } \\
\text { controlled trial of vitamin D supplementation } \\
\text { for the prevention of influenza and other re- } \\
\text { spiratory infections }\end{array}$ & $\begin{array}{l}\text { NIHR - Programme } \\
\text { Grants for Applied } \\
\text { Research }\end{array}$ & $\begin{array}{l}\text { Mar } 2010-\text { Apr } \\
2013 \text { (LTP) }\end{array}$ & $\begin{array}{l}12 \\
\text { months }\end{array}$ & $\begin{array}{l}108 \text { units, - } \\
\text { approx. } 3 \\
\text { participants } \\
\text { per unit }\end{array}$ & $\begin{array}{l}\text { Queen Mary } \\
\text { University } \\
\text { London }\end{array}$ \\
\hline VUE & $\begin{array}{l}\text { Two parallel randomised controlled trials of } \\
\text { surgical options for upper compartment (vault } \\
\text { or uterine) pelvic organ prolapse }\end{array}$ & NIHR-HTA & $\begin{array}{l}\text { Nov } 2012-\text { Jan } \\
2018\end{array}$ & $\begin{array}{l}12 \\
\text { months }\end{array}$ & 800 & $\begin{array}{l}\text { CHaRT, } \\
\text { University of } \\
\text { Aberdeen }\end{array}$ \\
\hline
\end{tabular}

${ }^{\mathrm{a}} \mathrm{CTIMP}$

Clearly the primary outcome is not the only thing that is important. One outcome is unlikely to provide all the information needed to make a judgement about the treatment being tested, meaning secondary outcomes are necessary. We also need to know something about harms, as well as cost. Participant identifiers and some data management and process information will also always be needed. Trials may also need to measure more than a single primary outcome.

In our sample the median proportion of secondary outcome data items is eight times that of the primary outcome. The ratio of non-outcome data to primary outcome data was similar. This might be fine. However, the undeniable design importance of the primary outcome, together with its importance to external judgements about the utility of the intervention, makes this distribution of attention look odd. At a minimum it is worthy of some reflection.

Our study raises three key questions:

1. Given that the primary outcome is the most important and (likely) the only fully powered outcome, is the substantially larger proportion of data collected for secondary outcomes justified?

2. Do people really appreciate how much nonoutcome data trials collect?

3. Does volume of data correlate with data collection effort?
Our study answers none of these questions. However, it does highlight how important it is to try to answer them. Data collection itself is hard work, and it generates additional work by requiring data management systems, quality assurance and, usually, data entry to deal with it. Given the undoubted importance of the primary outcome, we need to be sure that all outcomes in our set of secondary outcomes-many, if not all, underpoweredare worth the effort. If data collection effort does relate to data volume, then it seems disproportionate for trial teams to devote around eight times as much effort on the secondary outcomes as on the primary. Secondary outcomes may support understanding of the primary outcome result, but they are not the outcomes that trialists themselves consider to be of most importance. A new Trial Forge project called ORINOCO (Optimising Resource Use in Outcome Collection) will look at data collection effort by collecting time spent collecting primary and secondary outcomes (https://www.abdn.ac.uk/ hsru/what-we-do/research/projects/orinoco-826.php).

Why trial teams collect so much data is unclear but, anecdotally, we (and others) know that some investigators believe that since the participant is providing data anyway, why not collect a few more things? The work involved in doing this is unlikely to be borne by the person making the request. Items unrelated to the original aims of the trial are added, and trial team members have their own interests, and each adds something to the data collection job. Additional items can be added by Trial 
Table 3 Mean, min-max and median proportion values and total number of items for all 17 data categories across all trials

\begin{tabular}{|c|c|c|c|c|}
\hline Category & Mean & Min - Max & Median & $\begin{array}{l}\text { Total \# } \\
\text { of items }\end{array}$ \\
\hline Primary Outcome & $11.2 \%$ & $0.4-50.3 \%$ & $5.0 \%$ & 6,526 \\
\hline $\begin{array}{l}\text { Primary outcome but not primary } \\
\text { analysis }\end{array}$ & $0.7 \%$ & $0.0-5.3 \%$ & $0.0 \%$ & 164 \\
\hline Secondary Outcomes & $42.5 \%$ & $1.0-78.2 \%$ & $39.9 \%$ & 10,560 \\
\hline $\begin{array}{l}\text { Outcome data not listed as primary, } \\
\text { secondary or health economics outcome }\end{array}$ & $6.5 \%$ & $0.0-27.9 \%$ & $3.0 \%$ & 1,236 \\
\hline Items from a core outcome set & $0.0 \%$ & $0.0-0.1 \%$ & $0.0 \%$ & 1 \\
\hline Health Economics* & $2.7 \%$ & $0.0-25.3 \%$ & $0.0 \%$ & 762 \\
\hline Participant identification items & $4.8 \%$ & $0.0-10.6 \%$ & $4.9 \%$ & 912 \\
\hline Items needed for randomisation & $0.6 \%$ & $0.0-3.3 \%$ & $0.2 \%$ & 70 \\
\hline Eligibility & $2.3 \%$ & $0.0-16.8 \%$ & $0.9 \%$ & 270 \\
\hline Demographics & $1.1 \%$ & $0.0-6.9 \%$ & $0.5 \%$ & 146 \\
\hline Medical History & $2.5 \%$ & $0.0-8.4 \%$ & $1.7 \%$ & 491 \\
\hline Data Management Item & $5.6 \%$ & $0.2-12.0 \%$ & $5.8 \%$ & 1494 \\
\hline Safety Data & $7.7 \%$ & $0.0-24.7 \%$ & $4.7 \%$ & 1016 \\
\hline Regulatory Data & $4.7 \%$ & $0.0-13.1 \%$ & $2.9 \%$ & 538 \\
\hline Compliance Data & $6.0 \%$ & $0.0-22.6 \%$ & $3.6 \%$ & 1504 \\
\hline Process Outcomes & $0.2 \%$ & $0.0-2.9 \%$ & $0.0 \%$ & 63 \\
\hline Miscellaneous & $1.0 \%$ & $0.0-6.8 \%$ & $0.2 \%$ & 197 \\
\hline
\end{tabular}

Proportions of data items within each trial were calculated and those proportions summarised across all 18 trials. Items above the dividing line are considered outcome data, those under the line non-outcome data

${ }^{a}$ The Health economics category was only used when these outcomes were not explicitly listed as a primary or secondary outcome

Steering Groups and, for that matter, funders. The tendency always seems to be upwards when it comes to data collection.

That said, our own anecdotal experience, and that of others [16], is that when the going gets tough with outcome collection, trial teams quickly start to focus on getting just primary outcome data from participants. This brings into stark focus the relative importance of those secondary outcomes. Secondary outcomes can address related questions and provide context in which to interpret the primary outcome, but we need to keep their relative importance in mind when selecting how many of them to collect. For definitive Phase III trials such as those we selected, a secondary outcome, like the primary, should be essential to the people (generally patients, healthcare professionals and policymakers) whose decisions the trial is intended to support. Anything else is garnish, which has clear resource implications in the cash-limited world of publicly funded research.

The amount of non-outcome data was a surprise. That a median of just under $5 \%$ of all data collected is linked to the participant ID was not a result we expected, nor was the finding that internal data management items (e.g. ticking a box if a process was completed) was almost $6 \%$. Some of this cannot be avoided, but even here there is likely to be scope for efficiencies. For example, the proportion of data items linked to demographics ranged from 0 to $6.9 \%$, with a median of $0.5 \%$. Across most of our trials, around $2 \%$ of data were demographic. Trial designers should ask themselves at the beginning of trials what a reasonable volume of demographic (or other) data is, make sure they are resourced to collect at that level and have a clear use for these data once collected.

Our data underline that non-outcome data represent a substantial proportion of the data that participants need to provide and trial staff need to work with. Reducing the burden of trials on participants and staff was highlighted as an area in need of research to improve retention by the PRIORITY-2 project [10], and ways of assessing burden have been proposed [17]. One must also carefully choose the non-outcome data that will be collected so trial budgets and resource can be allocated proportionately. Those making policy and governance 
Table 4 Mean, min-max and median proportion values and total number of items for all categories across CTIMPs and non-CTIMPs

\begin{tabular}{|c|c|c|c|c|c|c|c|c|}
\hline \multirow[b]{2}{*}{ Category } & \multirow[b]{2}{*}{ Mean } & \multirow[b]{2}{*}{ Min - Max } & \multicolumn{3}{|c|}{ CTIMPs } & \multicolumn{2}{|c|}{ Non-CTIMPs } & \multirow[b]{2}{*}{$\begin{array}{l}\text { Total \# } \\
\text { of items }\end{array}$} \\
\hline & & & Median & $\begin{array}{l}\text { Total \# } \\
\text { of items }\end{array}$ & Mean & Min - Max & Median & \\
\hline Primary Outcome & $13.3 \%$ & $4.1-31.3 \%$ & $4.4 \%$ & 172 & $10.8 \%$ & $0.6-50.3 \%$ & $5.5 \%$ & $\begin{array}{c}6354 \\
(1258)^{*}\end{array}$ \\
\hline $\begin{array}{l}\text { Primary outcome but not primary } \\
\text { analysis }\end{array}$ & $0.0 \%$ & $0.0-0.0 \%$ & $0.0 \%$ & & $0.8 \%$ & $0.0-5.3 \%$ & $0.0 \%$ & \\
\hline Secondary Outcomes & $24.8 \%$ & $1.0-39.5 \%$ & $33.8 \%$ & 436 & $46.0 \%$ & $13.1-78.2 \%$ & $45.2 \%$ & $\begin{array}{l}10124 \\
(6594)^{*}\end{array}$ \\
\hline $\begin{array}{l}\text { Outcome data not listed as } \\
\text { primary, secondary or health } \\
\text { economics outcome }\end{array}$ & $0.9 \%$ & $0.0-2.3 \%$ & $0.4 \%$ & 18 & $7.6 \%$ & $0.0-27.9 \%$ & $3.3 \%$ & 1218 \\
\hline Items from a core outcome set & $0.0 \%$ & $0.0-0.0 \%$ & $0.0 \%$ & 0 & $0.0 \%$ & $0.0-0.1 \%$ & $0.0 \%$ & 1 \\
\hline Health Economics & $0.0 \%$ & $0.0-0.0 \%$ & $0.0 \%$ & 0 & $3.2 \%$ & $0.0-25.3 \%$ & $0.0 \%$ & 762 \\
\hline Participant identification items & $8.9 \%$ & $6.2-10.6 \%$ & $9.9 \%$ & 142 & $4.0 \%$ & $0.0-9.0 \%$ & $4.5 \%$ & 770 \\
\hline Items needed for randomisation & $0.9 \%$ & $0.4-1.9 \%$ & $0.5 \%$ & 17 & $0.5 \%$ & $0.0-3.3 \%$ & $0.2 \%$ & 53 \\
\hline Eligibility & $2.9 \%$ & $1.3-5.0 \%$ & $2.4 \%$ & 45 & $2.2 \%$ & $0.0-16.8 \%$ & $0.6 \%$ & 225 \\
\hline Demographics & $2.3 \%$ & $0.0-6.9 \%$ & $0.0 \%$ & 48 & $0.8 \%$ & $0.0-2.4 \%$ & $0.5 \%$ & 98 \\
\hline Medical History & $0.8 \%$ & $0.0-1.9 \%$ & $0.4 \%$ & 12 & $2.8 \%$ & $0.0-8.4 \%$ & $1.9 \%$ & 479 \\
\hline Data Management Item & $7.2 \%$ & $6.9-7.4 \%$ & $7.2 \%$ & 112 & $5.3 \%$ & $0.2-12.0 \%$ & $4.7 \%$ & 1382 \\
\hline Safety Data & $16.4 \%$ & $7.6-24.7 \%$ & $16.9 \%$ & 233 & $5.9 \%$ & $0.0-21.1 \%$ & $3.2 \%$ & 783 \\
\hline Regulatory Data & $11.7 \%$ & $10.6-13.1 \%$ & $11.5 \%$ & 178 & $3.3 \%$ & $0.0-11.8 \%$ & $1.9 \%$ & 360 \\
\hline Compliance Data & $9.5 \%$ & $0.6-22.6 \%$ & $5.4 \%$ & 129 & $5.3 \%$ & $0.0-21.1 \%$ & $3.5 \%$ & 1375 \\
\hline Process Outcomes & $0.0 \%$ & $0.0-0.0 \%$ & $0.0 \%$ & 0 & $0.3 \%$ & $0.0-2.9 \%$ & $0.0 \%$ & 63 \\
\hline Miscellaneous & $0.4 \%$ & $0.0-1.3 \%$ & $0.0 \%$ & 9 & $1.2 \%$ & $0.0-6.8 \%$ & $0.3 \%$ & 188 \\
\hline
\end{tabular}

${ }^{\text {a } T o t a l s ~ w i t h o u t ~ V i D i F l u ~ d a t a ~}$

decisions about research (e.g. sponsors, regulators) need to weigh up their requirements for non-outcome data against the work needed to collect and manage it. Although we only included three CTIMPs, the impact of regulation (or at least how regulation is interpreted) on data collection workload is visible: for our three CTIMPS a median of $11.5 \%$ of all data items collected were classed as regulatory, compared to $1.9 \%$ for nonCTIMPs. Regulatory decisions are capable of directly leading to thousands of extra items of data collection across hundreds of trials. Regulators need to be confident that, on balance, their requirements do more good than harm and increase the transparency of their requirements. Grey areas around what is needed to meet the conditions imposed can lead to over-collection of data, as researchers may not be clear about what exactly is required. Some of the potential harm is workload, particularly if conservative interpretation, or misinterpretation, of legislation by research administrators adds additional but unnecessary data collection requirements [18].

\section{Limitations and strengths}

Our work has limitations. The 18 included trials were a convenience sample rather than a random sample of published trials. We quickly found that the categorisation process required someone close to each included trial, and choosing trials that none of the team knew of made categorisation difficult. As such, we do not claim that our results are representative of all trials. However, all the included trials are real trials, not hypothetical ones, and they vary enormously in terms of trial teams, intervention, sample size and follow-up durations. We would be surprised if the headline result of substantially more data items dedicated to secondary outcomes than primary outcomes was overturned in a bigger sample. Our categorisation method (see Additional file 1) can be replicated by others for their own trials, and we could perhaps build up a larger sample over time.

Only three CTIMPs were included in our sample, which limits what we can say about a comparison between CTIMPs and non-CTIMPs. There appear to be more regulatory and safety data collected in CTIMPs, but to determine exactly how much requires rather more CTIMP trials. Moreover, some regulators (e.g. the UK's Medicines and Healthcare products Regulatory Agency, the MHRA) categorise CTIMPs by risk, which means that not only would we need a larger sample, but also a good mix of CTIMP risk categories.

The categories were not always exclusive, and much of the discrepancy discussion between the reviewers categorising each trial amounted to which category won out given that a case could be made for more than one. Our SOP and guidance provided some rules. Generally, we went with the emphasis given in the trial protocol for outcomes and tried to be consistent for non-outcome data. Different pairs of reviewers may have reached slightly different conclusions for some items of data, although we are confident that the process we used was as robust as it could be for these judgement-based decisions. 
There are some strengths too. The study idea came from trial managers and addressed a question that was very important to their trial front-line experience: what sorts of data are collected in trials? We are confident of the importance of the topic covered by this work. The study also involved staff with diverse roles from seven trials units in three regions with differing regulatory environments (England, Ireland and Scotland), which brought a range of perspectives. We have created a set of data categories, a SOP, guidance and some templates (see Table 1 and Additional file 1) that others can now use to assess their own trials, including at the design stage. Finally, the project started some new collaborations and has some simple messages that we think are worth all trialists' attention.

\section{Implications for practice}

1. For Phase III trials, we think trialists should continue to consult with patients, health professionals and policymakers to identify the outcomes they will need to inform their future decisions about the usefulness of the intervention being tested. Trialists should then resist requests to add to this list without having a compelling reason for collecting data not essential to stakeholders' future treatment decisions. Core outcome sets [19] may help.

2. Trial teams could consider categorising the data they propose collecting on their CRFs before they start to use them. They could then check that the distribution of data volume is what they anticipated and want. This information would support decision-making for resource allocation to collect, process and quality control the data.

\section{Implications for future research}

1. Measuring data collection effort. The time actually spent collecting data items is the focus of a new Trial Forge data collection project: ORINOCO will examine the time spent collecting primary and secondary outcomes (https://www.abdn.ac.uk/hsru/ what-we-do/research/projects/orinoco-826.php).

2. Expansion of this work to assess a larger number of trials potentially with a focus on CTIMPs, given the small sample included here, would be beneficial.

3. The work described here did not assess whether collected data were actually used, or published. Doing so would be a useful addendum to this work, perhaps along the lines of the study done by O'Leary et al. [11].

4. The impact on data volume and distribution of doing one or both items listed under 'Implications for practice' would be worth evaluating. Like anything else, they are only worth doing if they lead to benefit. We would anticipate that they will reduce both volume of data and number of outcomes, especially secondary outcomes, but this needs to be demonstrated.

\section{Conclusion}

Our results show that a small proportion of data collected in the studied trials was related to the primary outcome, while a substantial amount was not related to trial outcomes. Generally speaking, secondary outcomes account for eight times the volume of data as the primary outcome.

The data collection load is driven by the trial protocol. It is important that those designing trials ensure that the protocol focuses efforts on collecting data essential to support the health and treatment decisions of those whom the trial is designed to help. Collecting additional data threatens the key purpose of the trial and may be considered wasteful in the context of limited public funding for clinical research.

\section{Supplementary information}

Supplementary information accompanies this paper at https://doi.org/10. 1186/s13063-020-04388-x.

Additional file 1. Standard operating procedure for categorising data collected in trials

\section{Abbreviations}

CRF: Case report form; CTIMP: Clinical Trial of an Investigational Medicinal Product; ID: Identifier; SOP: Standard operating procedure; UKTMN: UK Trial Managers' Network

\section{Acknowledgements}

We would like to thank Joanne Palmer and all attendees of the 2015 workshop at the UK Trial Managers' Network meeting. We thank all Chief Investigators of the trials in our sample for giving their permission to use their trial data collections forms in our analysis: Annie S Anderson (ActWELL), Doreen McClurg (AMBER), Charles Knowles (CONFIDeNT), Augusto AzuaraBlanco (EAGLE), Frank Sullivan (ECLS), Shakila Thangaratinam (EMPiRE), Kevin Cooper (HEALTH), Eugene Dempsey (HIP), Craig Ramsay (iQUAD), lan Reid (KANECT), David Murray (KAT), Saruban Pasu (PIMS), Khalid S Khan (SALVO), Robert Pickard (SUSPEND), Anthony King (TAGS), Graham Devereux (TWICS), Adrian R Martineau (ViDiFlu), Charis Glazener (VUE). Similarly, we thank the funders of all the trials: Chief Scientist Office (CSO), Scottish Government Health Directorate; CSO, Scottish Government and Oncimmune Ltd; European Commission within the Seventh Framework Programme; National Institute for Health Research - Efficacy and Mechanism Evaluation (NIHR-EME); National Institute for Health Research - Health Technology Assessment (NIHR-HTA) programme; National Institute for Health Research - Programme Grants for Applied Research (NIHR-PGAR); the Scottish Government.

The Health Services Research Unit, University of Aberdeen, receives core funding from the CSO of the Scottish Government Health Directorates.

\section{Authors' contributions}

The original idea for this work came from the attendees of a workshop held at the annual meeting of the UK Trial Managers' Network (UKTMN) held in London, UK, on 10th September 2015 led by ST and involving DL. KB, SB, LC, $E C, A E, G F, H G, K G, D L, A M, E O, N S$ and ST developed the data categorisation standard operating procedure and discussed its use. KB, SB, LC, SC, EC, AD, 
$A E, G F, H G, K G, D L, E O, K S, N S, S T$ and MV categorised data in one or more of the 18 included trials. All authors contributed to discussions of the results. All authors contributed to writing this paper and approved the final draft.

\section{Funding}

The work had no external funding.

\section{Availability of data and materials}

Not applicable.

Ethics approval and consent to participate

Not applicable.

\section{Consent for publication}

Not applicable.

\section{Competing interests}

ST is an Editor-in-Chief of Trials. The other authors declare that they have no competing interests.

\section{Author details}

${ }^{1}$ Health Research Board Clinical Research Facility, University of Cork, Cork, Ireland. ${ }^{2}$ Health Services Research Unit, University of Aberdeen, Aberdeen, UK. ${ }^{3}$ Centre for Healthcare Randomised Trials, Health Services Research Unit, University of Aberdeen, Aberdeen, UK. ${ }^{4}$ Nursing, Midwifery and Allied Health Professions (NMAHP) Research Unit, Glasgow Caledonian University, Glasgow, UK. Institute of Population Health Sciences, Queen Mary University of London, London, UK. ${ }^{6}$ Primary Care Clinical Trials Unit, University of Oxford, Oxford, UK. ${ }^{7}$ Pragmatic Clinical Trials Unit, Queen Mary University of London, London, UK. ${ }^{8}$ Birmingham Clinical Trials Unit, University of Birmingham, Birmingham, UK.

Received: 10 December 2019 Accepted: 6 May 2020

Published online: 16 June 2020

\section{References}

1. Friedman L, Furberg C, DeMets D. Data collection and quality control. Fundamentals of clinical trials. New York: Springer; 2010. p. 199-214.

2. Moher D, Hopewell S, Schulz KF, Montori V, Gøtzsche PC, Devereaux PJ, Elborne D, Egger M, Altman DG. CONSORT 2010 Explanation and Elaboration: updated guidelines for reporting parallel group randomised trials. BMJ. 2010;340:c869.

3. Getz KA, Stergiopoulos S, Marlborough M, Whitehill J, Curran M, Kaitin Kl. Quantifying the magnitude and cost of collecting extraneous protocol data. Am J Ther. 2015:22:117-24.

4. Getz K. Improving protocol design feasibility to drive drug development economics and performance. Int J Environ Res Public Health. 2014;11: 5069-80.

5. Al-Shahi Salman R, Beller E, Kagan J, Hemminki E, Phillips RS, Savulescu J, Macleod M, Wisely J, Chalmers I. Increasing value and reducing waste in biomedical research regulation and management. Lancet. 2014;383:176-85.

6. Fougerou-Leurent C, Laviolle B, Tual C, et al. Impact of a targeted monitoring on data-quality and data-management workload of randomized controlled trials: a prospective comparative study. Br J Clin Pharmacol. 2019; 85:2784-92 10.1111/bcp.14108.

7. Getz K, Campo R. New benchmarks characterizing growth in protocol design complexity. Ther Innov Regul Sci. 2018;52(1):22-8.

8. Getz K, Wenger J, Campo R, Seguine E, Kaitin K. Assessing the impact of protocol design changes on clinical trial performance. Am J Ther. 2008;15:450-7.

9. Brintnall-Karabelas J, Sung S, Cadman M, Squires C, Whorton K, Pao M. Improving recruitment in clinical trials: why eligible patients decline. J Empir Res Hum Res Ethics. 2011;6(1):69-74.

10. Brunsdon D, Biesty L, Brocklehurst P, Brueton V, Devane D, Elliott J, Galvin S, Gamble C, Gardner H, Healy P, Hood K, Jordan J, Lanz D, Maeso B, Roberts A, Skene I, Soulsby I, Stewart D, Torgerson D, Treweek S, Whiting C, Worrall A, Gillies K. What are the most important unanswered research questions in trial retention? A James Lind Alliance Priority Setting Partnership: the PRioRiTy II (Prioritising Retention in Randomised Trials) study. Trials 2019;20(1):593. https://doi.org/10.21203/rs.2.439/v1.
11. Kang $\mathrm{H}$. The prevention and handling of the missing data. Korean J Anesthesiol. 2013;64(5):402-6.

12. O'Leary $\mathrm{E}$, Seow $H$, Julian J, Levine M, Pond G. Data collection in cancer clinical trials: too much of a good thing? Clin Trials. 2013;10:624-32.

13. McClurg D, Goodman K, Hagen S, Harris F, Treweek S, Emmanuel A, Norton C, Coggrave M, Doran S, Norrie J, Donnan P, Mason H, Manoukian S. Abdominal massage for neurogenic bowel dysfunction in people with multiple sclerosis (AMBER — Abdominal Massage for Bowel Dysfunction Effectiveness Research): study protocol for a randomised controlled trial. Trials. 2017;18:150.

14. Murray DW, Maclennan GS, Breeman S, Dakin HA, Johnston L, Campbell MK, et al. A randomised controlled trial of the clinical effectiveness and costeffectiveness of different knee prostheses: the Knee Arthroplasty Trial (KAT). Health Technol Assess. 2014;18(19):1. https://doi.org/10.3310/hta18190.

15. Khan KS, Moore P, Wilson M, Hooper R, Allard S, Wrench I, Roberts T, McLoughlin C, Beresford L, Geoghegan J, Daniels J, Catling S, Clark VA, Ayuk P, Robson S, Gao-Smith F, Hogg M, Jackson L, Lanz D, Dodds J. A randomised controlled trial and economic evaluation of intraoperative cell salvage during caesarean section in women at risk of haemorrhage: the SALVO (cell SALVage in Obstetrics) trial. Health Technol Assess. 2018;22(2):1-88.

16. Daykin A, Clement C, Gamble C, Kearney A, Blazeby J, Clarke M, Lane JA, Shaw A. "Recruitment, recruitment, recruitment" - the need for more focus on retention: a qualitative study of five trials. Trials. 2018;19:76.

17. Lingler $J H$, Schmidt $K L$, Gentry $A L$, Hu L, Terhorst LA. A new measure of research participant burden: brief report. J Empir Res Hum Res Ethics. 2014;9:46-9.

18. Brown MJ. The impact of clinical trials legislation on clinical pharmacology: problems and solutions. Br J Clin Pharmacol. 2009;67:487-93.

19. Gargon E, Williamson PR, Altman DG, Blazeby JM, Tunis S, Clarke M. The COMET Initiative database: progress and activities update (2015). Trials. 2017;18:54.

\section{Publisher's Note}

Springer Nature remains neutral with regard to jurisdictional claims in published maps and institutional affiliations.

Ready to submit your research? Choose BMC and benefit from:

- fast, convenient online submission

- thorough peer review by experienced researchers in your field

- rapid publication on acceptance

- support for research data, including large and complex data types

- gold Open Access which fosters wider collaboration and increased citations

- maximum visibility for your research: over $100 \mathrm{M}$ website views per year

At BMC, research is always in progress.

Learn more biomedcentral.com/submissions 